\title{
Close association between polymorphisms of the nitric oxide synthetase 3 gene and neurological disorders other than stroke
}

This article was published in the following Dove Press journal:

International Journal of General Medicine

10 May 2012

Number of times this article has been viewed

\section{Shailendra Kapoor}

Richmond, VA, USA
Correspondence: Shailendra Kapoor

2300 E Cary Street, Richmond,

VA 23223, USA

Email shailendrakapoor@yahoo.com

\section{To the editor}

I read with great interest the article by Du et al in a recent issue of your journal. ${ }^{1}$ The article makes highly interesting reading. Interestingly, the past few years have seen the discovery of a number of close associations between polymorphisms of the nitric oxide synthetase 3 (NOS3) gene and neurological diseases other than stroke.

For instance, increased expression of NOS3 results in altered mitochondrial function in neurons. As a consequence, the intracellular levels of reactive oxygen species are accentuated, as are the levels of p53 and Bax, resulting in the dementia and neurodegeneration seen in individuals with Alzheimer's disease. ${ }^{2}$ The G894T polymorphism acts as a risk factor for sporadic frontotemporal lobar degeneration. In fact, in a recent study, Venturelli et al have reported an incidence rate of $40 \%$ for the G894T polymorphism in individuals afflicted with frontotemporal lobar degeneration. ${ }^{3}$ Similarly, the risk of post-stroke dementia is increased in stroke patients with the rs 1799983 polymorphism of the NOS3 gene. For instance, the hazard ratio is 3.14 in stroke patients with the TT genotype in comparison with those having the GG genotype. ${ }^{4}$

Similarly, individuals with Pick's disease and Lewy body disease demonstrate altered NOS3 expression and accelerated proliferation of NOS3-positive neurons. ${ }^{5}$ An increased incidence of Parkinson's disease is also associated with the rs 12829185 and rs3782218 polymorphisms of the NOS1 gene and the rs 944725 polymorphism of the NOS2A gene. ${ }^{6}$ Further, Sohn et al have recently demonstrated increased proliferation of NOS3-expressing glial cells in amyotrophic lateral sclerosis, as well as in progressive supranuclear palsy. ${ }^{5}$

The above examples illustrate a clear association between NOS3 and many neurological diseases, ranging from Alzheimer's disease to Pick's disease. Modulation of NOS3 function may alter and beneficially attenuate the progression of these diseases. Hopefully, the coming years will see the development of these NOS3 modulators.

\section{Disclosure}

The author reports no conflicts of interest in this work.

\section{References}

1. Du D, Gao P, Hu L, et al. A genetic study of the NOS3 gene for ischemic stroke in a Chinese population. Int J Gen Med. 2008;1:65-68.

2. de la Monte SM, Chiche J, von dem Bussche A, et al. Nitric oxide synthase-3 overexpression causes apoptosis and impairs neuronal mitochondrial function: relevance to Alzheimer's-type neurodegeneration. Lab Invest. 2003;83:287-298. 
3. Venturelli E, Villa C, Fenoglio C, et al. The NOS3 G894T (Glu298Asp) polymorphism is a risk factor for frontotemporal lobar degeneration. Eur J Neurol. 2009;16:37-42.

4. Morris CM, Ballard CG, Allan L, et al. NOS3 gene rs 1799983 polymorphism and incident dementia in elderly stroke survivors. Neurobiol Aging. 2011;32:554.e1-e6.
5. Sohn YK, Ganju N, Bloch KD, Wands JR, de la Monte SM. Neuritic sprouting with aberrant expression of the nitric oxide synthase III gene in neurodegenerative diseases. J Neurol Sci. 1999;162:133-151.

6. Hancock DB, Martin ER, Vance JM, Scott WK. Nitric oxide synthase genes and their interactions with environmental factors in Parkinson's disease. Neurogenetics. 2008;9:249-262.

\section{Publish your work in this journal}

The International Journal of General Medicine is an international, peer-reviewed open-access journal that focuses on general and internal medicine, pathogenesis, epidemiology, diagnosis, monitoring and treatment protocols. The journal is characterized by the rapid reporting of reviews, original research and clinical studies across all disease areas.
A key focus is the elucidation of disease processes and management protocols resulting in improved outcomes for the patient.The manuscript management system is completely online and includes a very quick and fair peer-review system. Visit http://www.dovepress.com/ testimonials.php to read real quotes from published authors.

Submit your manuscript here: http://www.dovepress.com/international-journal-of-general-medicine-journal 